\title{
A dose of medicine on the Hill
}

\author{
The success of 'Mini-Med Schools' across the United States has prompted the \\ opening of one for the people who help make fundamental decisions about research.
}

The antiseptic smell of ethanol; the delicate clicking of microcentrifuge tube lids; experimenters bending over their work, exclaiming triumphantly as DNA precipitates out of solution before their eyes: Such sights, sounds and smells define the modern molecular biology laboratory. But this laboratory is unlike any other; it is temporarily located in the US House of Representatives' hearing room for the House Cornmittee on Science. The excited researchers are congressional staffers, getting a 'hands-on' demonstration of basic molecular biology at a 'Mini-Med School' on Capitol Hill sponsored jointly by the US National Institutes of Health (NIH) and the Association of American Medical Colleges (AAMC). The four-week course of study, taught by several of the best scientists NIH has to offer, is designed to educate the staffers about the state-ofthe-art medical research over which some of their congressional bosses have considerable financial influence.

The Capitol Hill classes have been popular, drawing more than 100 participants at each session. "We are ecstatic about the response we've gotten," says Jordan Cohen, president of AAMC. "But, after all, this is an opportunity to learn from some of the most gifted teachers at NIH who are also involved with the key advances in medical science." The course featured weekly twohour lectures by National Cancer Institute (NCI) Director Richard Klausner, $\mathrm{NIH}$ Director Harold Varmus, National Institute of Allergy and Infectious Diseases (NIAID) Director Anthony Fauci, and National Center for Human Genome Research Director Francis Collins. "Every medical school in the country would be envious of the faculty I have as 'dean' of this school," says Cohen. Staffers who attended all the sessions were granted a 'diploma' at the end of the last one.

The Mini-Med School concept was started in 1990 at the University of Colorado, and has since appeared in various forms all across the United States as a way to educate the public about the process and findings of modern medical science. However, the Capitol Hill version appears to have other motives as well, although its organizers vigorously deny this. Bruce Fuchs, a researcher at the Medical College of Virginia who successfully developed Mini-Med School programmes in Richmond and is now 'on loan' to NIH to coordinate its MiniMed School programmes, says that the Capitol Hill Mini-Med School serves exactly the same purpose as any others. "The key thing we are providing is a science lesson," Fuchs says. "This is not a lobbying effort." Cohen agrees: "I think it is important to emphasize that there is nothing about this that in any way can be called 'lobbying'. We are instead

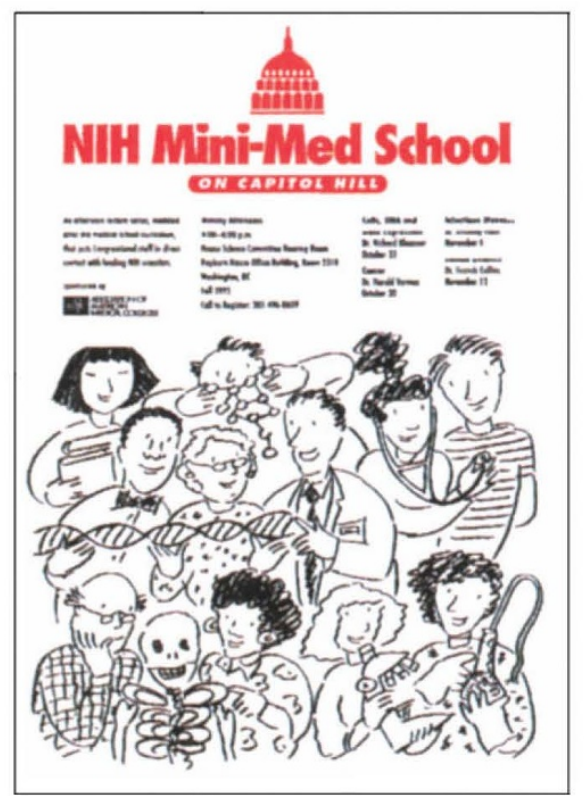

Poster announcing Hill Mini-Med School.

trying to increase the level of understanding [of basic medical science] so people are more informed."

Lobbying or not, both the low-key educational approach and calibre of instructor are appreciated by the Hill staffers who have found the time to devote to the course. "This has really helped me comprehend things I see in the news better," says Holly Baker, press secretary for Representative Lee Hamilton (Democrat, Indiana). "For example, three days after hearing Dr Varmus talk about cancer there was a big article in the New York Times about breast cancer genes that was easier to understand, given that he had just gone over it." Jeff Freeman, counsel/parliamentarian of the House Judiciary Committee, says such a highpowered educational opportunity is "one of the benefits of working up here. It's not very often you get the heads of NIH, NCI, NIAID and the Genome Project trying to get people to understand what the issues are."

Even though the organizers insist that there is no direct lobbying, this educational effort can only pay off in the long run. "Most of the people involved in this are people who have some relationship to $\mathrm{NIH}$, people who cover NIH on the Hill, health subcommittee members, and so forth," says one staffer attending the sessions. "This is bound to be of some assistance to them [NIH]." The excitement expressed by the Democratic chief of staff of the science committee over the programme also supports this: "He said that he hadn't seen anything like this in his fifteen years on the Hill, and that he has had the problem of getting legislative analysts on board who didn't know any science, but who were supposed to work on science issues," says Fuchs. "So we are really pleased with the large number of key legislative analysts and staff people showing up."

The strategic importance of having such students is not ignored by the director-of-NIH-institute instructors, either. "These are the individuals who help make fundamental decisions about research directions, and we feel it is a wonderful opportunity to offer them insight into the nature of what we are doing and to share our understanding of the value and excitement of modern science," says Klausner, whose class kicked off the series. Plans are under way for more educational opportunities of this type for staffers who work on science-related issues, including an on-campus laboratory class at NIH.

"We're in tough times, and tough decisions are going to have to be made," says Fuchs. "We all feel more comfortable knowing that the key staff up there understand science and base the decisions they are going to have to make on the science involved."

FinTAN R. STEELE 